\section{ANALISIS PEMAHAMAN MAHASISWA DALAM MATA KULIAH STRUKTUREN UND WORTSCHATZ II DITINJAU DARI ASPEK PERSEPSI}

\author{
Mantasiah R. ${ }^{1}$, Amir ${ }^{2}$, Yusri ${ }^{3}$, Muhammad Anwar ${ }^{4}$ \\ Universitas Negeri Makassar ${ }^{1,2,4}$ \\ Universitas Fajar, Makassar ${ }^{3}$ \\ Email: mantasiah@Uunm.ac.id¹
}

http://ojs.unm.ac.id/index.php/Insani/index

\begin{abstract}
Abstrak. Tujuan dari penelitian ini ialah untuk menganalisis tingkat pemahaman mahasiswa dalam mata kuliah sturukturen und wortschatz II ditinjau dari aspek persepsi. Jenis penelitian yang digunakan yakni deskriptif kuantitatif yang bertujuan untuk menggambarkan pemahaman mahasiswa dalam mata kuliah sturukturen und wortschatz II. Teknik pengumpulan data terdiri atas angket dan wawancara. Angket yang dikembangkan menggunakan skala semantic differential mulai interval 1 (tidak paham) sampai 6 (sangat paham) yang terdiri atas 10 item dimana setiap item mewakili satu materi dari topik sturukturen und wortschatz II. Jumlah partisipan yakni sebanyak 50 mahasiswa yang merupakan mahasiswa bahasa Jerman semester 4 yang telah memprogramkan mata kuliah sturukturen und wortschatz II yang berasal dari 3 universitas yang berbeda yakni Universitas Negeri Makassar, Universitas Negeri Jakarta, dan Universitas Negeri Yogyakarta. Teknik analisis data yakni statistik deskriptif dengan menggunakan teknik persentase. Hasil penelitian menunjukkan bahwa materi mengenai penggunaan preposisi yang menguasai akkusativ dan dativ, materi konjugasi kata sifat, serta materi tingkat perbandingan kata sifat menjadi kesulitan bagi mahasiswa dibandingkan dengan materi-materi lainnya. Selain itu terdapat beberapa materi yang mudah dipahami oleh mahasiswa seperti penggunaan possessivpronomen, modal verben, dan penggunaan nebensatz.
\end{abstract}

Kata Kunci: Sturukturen Und Wortschatz II, Tatabahasa, Bahasa Jerman, Persepsi

\section{INDONESIAN JOURNAL OF EDUCATIONAL STUDIES (IJES)}

\section{E-ISSN: 2621-6744 \\ P-ISSN: 2621-6736}

Submitted: May, 26 2019

Accepted : June, $3^{\text {rd }} 2019$

Abstract. The purpose of this study was to analyze the level of understanding of students in the subject sturukturen und wortschatz II in terms of perceptual aspects. The type of research used is descriptive quantitative. Data collection techniques consist of questionnaires and interviews. Questionnaires developed using semantic differential scales ranging from intervals 1 (do not understand) to 6 (very familiar) consisting of 10 items where each item represents one material from the topic sturukturen und wortschatz II. The number of participants is 50 students who are 4th semester German language students who have programmed sturukturen und wortschatz II courses. The data analysis technique is descriptive statistics using percentage techniques. The results showed that the material regarding the use of prepositions that mastered accusative and dative, adjective conjugation material, and material adjective level comparison became difficulties for students compared to other materials. In addition, there are several materials that are easily understood by students such as the use of possessiveness, verben capital, and the use of nebensatz. 


\section{PENDAHULUAN}

Beberapa penelitian yang dilakukan oleh Mantasiah \& Yusri (2017; 2018), Mantasiah et all. (2018), Yusri (2016) menunjukkan bahwa pembelajar Bahasa Jerman masih sering mengalami berbagai kesulitan, baik pada tataran pemahaman maupun pada tataran produksi. Namun secara umum kesulitan yang paling sering dihadapi oleh pembelajar Bahasa Jerman tersebut yakni terkait sulitnya memahami tatabahasa Jerman. Kesulitan dalam memahami tata bahasa Jerman salah satunya disebabkan karena sebagian besar buku bahan ajar Bahasa Jerman yang digunakan tidak mempertimbangkan aspek-aspek linguistik dari bahasa Jerman maupun bahasa dari pembelajar yakni bahasa Indonesia. Padahal salah satu aspek yang seharusnya diperhatikan dalam penyusunan buku ajar tatabahasa yakni dari aspek linguistik dari bahasa tersebut. Aspek linguistik tidak dapat dipisahkan dalam pengajaran bahasa khususnya dalam penyusunan bahan ajar, karena hal tersebut dapat mendukung proses pembelajaran menjadi lebih baik (McDonough, 2017; Litosseliti, 2017; Aronoff, 2017; Linares \& Morton ,2017; Aydinli \& Ortactepe, 2018).

Salah satu aspek linguistik yang seharusnya ada dalam penyusunan buku bahan ajar tata Bahasa Jerman adalah analisis awal terkait kesalahan-kesalahan apa yang sering dialami oleh pembelajar bahasa Jerman dengan menggunakan pendekatan Error Analysis. Setelah mengetahui kesalahan-kesalahan yang sering dilakukan oleh pembelajar, pendidik dapat menekankan ataupun memberikan porsi yang lebih banyak terhadap materi tersebut dalam penyusunan buku ajar tatabahasa (Hinkel, 2018; Song, 2018; Pangaribuan et al., 2018). Penelitian ini menjelaskan tingkat pemahaman mahasiswa terkait materi tatabahasa bahasa jerman khususnya pada mata kuliah sturukturen und wortschatz II yang ditinjau dari aspek persepsi.

Luaran dari penelitian ini yakni berupa rekomendasi terkait materi-materi yang dianggap sulit untuk dipahami oleh mahasiswa sehingga membutuhkan alokasi waktu yang lebih ataupun penekanan yang lebih dibandingkan materi-materi lainnya. Hasil penelitian inilah yang dijadikan dasar dalam menyusun buku tatabahasa, sehingga buku yang dikembangkan tersebut berbasis analisis kebutuhan pembelajar.

\section{METODE PENELITIAN}

Jenis penelitian yang digunakan yakni deskriptif kuantitatif yang bertujuan untuk menggambarkan pemahaman mahasiswa dalam mata kuliah sturukturen und wortschatz II. Teknik pengumpulan data terdiri atas angket dan wawancara. Angket yang dikembangkan menggunakan skala semantic differential mulai interval 1 (tidak paham) sampai 6 (sangat paham) yang terdiri atas 10 item dimana setiap item mewakili satu materi dari topik sturukturen und wortschatz II. Jumlah partisipan yakni sebanyak 50 mahasiswa yang merupakan mahasiswa bahasa Jerman semester 4 yang telah memprogramkan mata kuliah sturukturen und wortschatz II yang berasal dari 3 universitas yang berbeda yakni Universitas Negeri Makassar, Universitas Negeri Jakarta, dan Universitas Negeri Yogyakarta. Teknik analisis data yakni statistik deskriptif dengan menggunakan teknik persentase. 


\section{HASIL DAN PEMBAHASAN}

Pada tabel 1 dapat dilihat gambaran umum Pemahaman mahasiswa dalam mata kuliah sturukturen und wortschatz II yang terdiri atas 10 materi pelajaran.

Tabel 1. Gambaran Umum Pemahaman Mahasiswa

\begin{tabular}{clc}
\hline No & \multicolumn{1}{c}{ Materi } & Rata-Rata \\
\hline 1 & $\begin{array}{l}\text { Penggunaan Possessivpronomen (Kata Ganti Kepunyaan) } \\
\text { pada kasus nominatif }\end{array}$ & 5,6 \\
\hline 2 & $\begin{array}{l}\text { Penggunaan Possessivpronomen pada kasus akusativ dan } \\
\text { dativ }\end{array}$ & 5,05 \\
\hline 3 & Jenis-jenis Preposisi yang menguasai Akusativ dan Dativ & 3,67 \\
\hline 4 & Penggunaan Nebensatz - weill dan dass & 5,25 \\
\hline 5 & $\begin{array}{l}\text { Penggunaan Komparation der Adjektive mit wie und als - } \\
\text { Tingkat Perbandingan Kata Sifat }\end{array}$ & 4,05 \\
\hline 6 & $\begin{array}{l}\text { Penggunaan Modal Verben (Kata Kerja Bantu) } \\
\text { Membuat Kalimat Perfekt dan Prateritum dalam bahasa }\end{array}$ & 4,15 \\
\hline 8 & $\begin{array}{l}\text { Jerman } \\
\text { Mengubah Kalimat aktif menjadi Kalimat Pasif dalam bahasa }\end{array}$ & 4,7 \\
\hline 9 & Penggunaan Relativsatz dalam Bahasa Jerman & 4,1 \\
\hline 10 & $\begin{array}{l}\text { Penggunaan die Adjektivdeklination atau Konjugasi Kata } \\
\text { Sifat }\end{array}$ & 4,05 \\
\hline
\end{tabular}

Pada tabel 1 dapat dilihat bahwa materi mengenai penggunaan preposisi yang menguasai akkusativ dan dativ menjadi kesulitan bagi mahasiswa dibandingkan dengan materi-materi lainnya. Selain itu terdapat beberapa materi yang mudah dipahami oleh mahasiswa seperti penggunaan possessivpronomen, modal verben, dan penggunaan nebensatz. Untuk lebih jelasnya mengenai gambaran umum respon mahasiswa terhadap setiap materi dapat dilihat pada penjelasan berikut:

Penggunaan Possessivpronomen (Kata Ganti Kepunyaan) pada Kasus Nominatif

Tabel 2 menunjukkan pemahaman mahasiswa pada materi Possessivpronomen pada kasus nominatif, untuk lebih jelasnya dapat dilihat pada tabel 2 : 
Tabel 2. Pemahaman Mahasiswa mengenai Materi Possessivpronomen pada kasus nominatif

\begin{tabular}{ccc} 
Interval Nilai & Frekuensi & Persentase (\%) \\
\hline 1 & 0 & 0 \\
\hline 2 & 0 & 0 \\
\hline 3 & 0 & 0 \\
\hline 4 & 0 & 40 \\
\hline 5 & 16 & 60 \\
\hline 6 & 24 & $\mathbf{1 0 0}$
\end{tabular}

Tabel di atas menunjukkan bahwa $60 \%$ partisipan sangat paham akan materi Possessivpronomen pada kasus nominatif. Hal tersebut menunjukkan bahwa materi ini mudah dipahami sehingga tidak membutuhkan alokasi waktu yang lama ataupun penekanan dalam pembelajaran sturukturen und wortschatz II kedepannya.

Penggunaan Possessivpronomen pada Kasus Akusativ dan Dativ

Tabel 3 menunjukkan pemahaman mahasiswa pada Materi Possessivpronomen pada kasus Akusativ dan Dativ, untuk lebih jelasnya dapat dilihat pada tabel 3:

Tabel 3. Pemahaman Mahasiswa mengenai Materi Possessivpronomen pada kasus Akusativ dan Dativ

\begin{tabular}{ccc} 
Interval Nilai & Frekuensi & Persentase (\%) \\
\hline 1 & 0 & 0 \\
\hline 2 & 0 & 0 \\
\hline 3 & 0 & 32,5 \\
\hline 4 & 13 & 30 \\
\hline 5 & 12 & 37,5 \\
\hline 6 & 15 & $\mathbf{1 0 0}$
\end{tabular}

Tabel 3 menunjukkan bahwa sebagian besar mahasiswa berada pada kategori sangat paham pada materi Possessivpronomen pada kasus Akusativ dan Dativ. Namun materi ini bagi beberapa mahasiswa tergolong lumayan sulit untuk dipahami jika dibandingkan dengan materi sebelumnya yakni Possessivpronomen pada kasus nominatif.

Jenis-jenis Preposisi yang menguasai Akusativ dan Dativ

Tabel 4 menunjukkan pemahaman mahasiswa pada Materi Preposisi yang menguasai Akusativ dan Dativ, untuk lebih jelasnya dapat dilihat pada tabel 4: 
Tabel 4. Pemahaman Mahasiswa mengenai Preposisi yang menguasai Akusativ dan Dativ

\begin{tabular}{ccc} 
Interval Nilai & Frekuensi & Persentase \\
\hline 1 & 0 & 0 \\
\hline 2 & 0 & 0 \\
\hline 3 & 13 & 32,5 \\
\hline 4 & 27 & 67,5 \\
\hline 5 & 0 & 0 \\
\hline 6 & 0 & $\mathbf{1 0 0}$
\end{tabular}

Tabel 4 menunjukkan bahwa materi mengenai Preposisi yang menguasai Akusativ dan Dativ menjadi salah satu kesulitas yang dialami oleh mahasiswa, terbukti dari hasil analisis data yang menunjukkan bahwa sebagian besar mahasiswa berada pada kategori 3 dan 4. Hal ini mengindikasikan bahwa tidak ada mahasiswa yang menganggap materi ini sangat mudah ataupun mudah untuk dipahami.

Penggunaan Nebensatz - Weill dan Dass

Tabel 5 menunjukkan pemahaman mahasiswa pada Materi Nebensatz, untuk lebih jelasnya dapat dilihat pada tabel 5 :

Tabel 5. Pemahaman Mahasiswa mengenai Nebensatz

\begin{tabular}{ccc} 
Interval Nilai & Frekuensi & Persentase \\
\hline 1 & 0 & 0 \\
\hline 2 & 0 & 0 \\
\hline 3 & 0 & 0 \\
\hline 4 & 5 & 12,5 \\
\hline 5 & 20 & 50 \\
\hline 6 & 15 & $\mathbf{1 0 0}$
\end{tabular}

Materi Nebensatz juga tidak menjadi terlalu rumit bagi mahasiwa, dimana sebagai besar mahasiswa berada pada kateori 5 dan 6 . Hal tersebut menunjukkan bahwa materi ini juga tidak membutuhkan alokasi waktu yang banyak untuk diajarkan kepada mahasiswa.

Penggunaan Komparation der Adjektive mit wie und als

Tabel 6 menunjukkan pemahaman mahasiswa pada Materi Komparation der Adjektive mit wie und als, untuk lebih jelasnya dapat dilihat pada tabel 6: 
Tabel 6. Pemahaman Mahasiswa mengenai Tingkat Perbandingan Kata Sifat

\begin{tabular}{ccc} 
Interval Nilai & Frekuensi & Persentase \\
\hline 1 & 0 & 0 \\
\hline 2 & 0 & 0 \\
\hline 3 & 7 & 17,5 \\
\hline 4 & 22 & 55 \\
\hline 5 & 9 & $\mathbf{2 2 , 5}$ \\
\hline 6 & 2 & $\mathbf{1 0 0}$
\end{tabular}

Materi Komparation der Adjektive mit wie und als merupakan salah satu materi yang perlu ditekankan dalam pembelajaran tatabahasa dibandingkan dengan materi lainnya. Materi ini juga membutuhkan alokasi waktu yang lebih untuk dijelaskan kepada mahasiswa. Hal tersebut terbukti dari hasil analisis data tabel 6 yang menujukkan bahwa sebagian besar mahasiswa berada pada kategori 4.

Penggunaan Modal Verben (Kata Kerja Bantu)

Tabel 7 menunjukkan pemahaman mahasiswa pada Materi Modal Verben, untuk lebih jelasnya dapat dilihat pada tabel 7:

Tabel 7. Pemahaman Mahasiswa mengenai Modal Verben

\begin{tabular}{ccc} 
Interval Nilai & Frekuensi & Persentase \\
\hline 1 & 0 & 0 \\
\hline 2 & 0 & 0 \\
\hline 3 & 0 & 0 \\
\hline 4 & 0 & 0 \\
\hline 5 & 19 & 57,5 \\
\hline 6 & 21 & $\mathbf{1 0 0}$
\end{tabular}

Modal verben dianggap sebagai materi yang mudah dipahami oleh mahasiswa. Hal tersebut ditunjukkan dari tabel 7 yang menjelaskan bahwa sebagian besar mahasiswa yakni 52,5\% berada pada kategori 6 dalam artian mahasiswa sangat paham akam materi modal verben.

Membuat Kalimat Perfekt dan Prateritum dalam bahasa Jerman

Tabel 8 menunjukkan pemahaman mahasiswa pada Materi Kalimat Perfekt dan Prateritum, untuk lebih jelasnya dapat dilihat pada tabel 8: 
Tabel 8. Pemahaman Mahasiswa mengenai Kalimat Perfekt dan Prateritum

\begin{tabular}{ccc} 
Interval Nilai & Frekuensi & Persentase \\
\hline 1 & 0 & 0 \\
\hline 2 & 0 & 0 \\
\hline 3 & 2 & 32,5 \\
\hline 4 & 13 & 50 \\
\hline 5 & 20 & 12,5 \\
\hline 6 & 5 & $\mathbf{1 0 0}$
\end{tabular}

Tabel 8 menunjukkan bahwa sebagian besar mahasiswa menganggap materi perfekt dan prateritum menjadi materi yang lumayan sulit untuk dipahami. Sebagian besar mahasiswa yakni dengan persentase $50 \%$ dan 32,5\% berada pada kategori 5 dan 4 secara berurutan. Hal tersebut mengindikasikan bahwa materi ini perlu penambahan alokasi waktu serta perlu ditekankan dalam pembelajaran dibandingkan beberapa materi lainnya.

Kalimat aktif menjadi Kalimat Pasif dalam bahasa Jerman

Tabel 9 menunjukkan pemahaman mahasiswa pada Materi Kalimat aktif menjadi Kalimat Pasif, untuk lebih jelasnya dapat dilihat pada tabel 9:

Tabel 9. Pemahaman Mahasiswa mengenai Kalimat aktif menjadi Kalimat Pasif

\begin{tabular}{ccc} 
Interval Nilai & Frekuensi & Persentase \\
\hline 1 & 0 & 0 \\
\hline 2 & 0 & 0 \\
\hline 3 & 2 & 5 \\
\hline 4 & 13 & 52,5 \\
\hline 5 & 20 & 12,5 \\
\hline 6 & 5 & $\mathbf{1 0 0}$
\end{tabular}

Seperti halnya dengan materi perfekt dan prateritum, materi kalimat pasiv juga dianggap rumit dipahami oleh mahasiswa. Hal tersebut terbukti dari data yang disajikan pada tabel 9 dimana sebagian besar mahasiswa dengan persentase $50 \%$ dan 32,5\% berada pada kategori 5 dan 4 .

\section{Penggunaan Relativsatz dalam Bahasa Jerman}

Tabel 10 menunjukkan pemahaman mahasiswa pada Materi Relativsatz, untuk lebih jelasnya dapat dilihat pada tabel 10: 
Tabel 10. Pemahaman Mahasiswa mengenai Materi Relativsatz

\begin{tabular}{ccc} 
Interval Nilai & Frekuensi & Persentase \\
\hline 1 & 0 & 0 \\
\hline 2 & 0 & 0 \\
\hline 3 & 12 & 30 \\
\hline 4 & 14 & 35 \\
\hline 5 & 12 & 30 \\
\hline 6 & 2 & $\mathbf{1 0 0}$
\end{tabular}

Salah satu materi yang paling sulit bagi mahasiswa yakni materi relatvsatz. Hal tersebut terbukti dari data yang disajikan pada tabel 10 dimana sebagain besar mahasiswa berada pada kategori 3, 4 dan 5. Hal tersebut mengindikasikan bahwa materi ini membutuhkan alokasi waktu yang lebih banyak dibandingkan biasanya, sehingga perlu penekanan yang lebih dalam proses pembelajaran.

\section{Penggunaan die Adjektivdeklination atau Konjugasi Kata Sifat}

Tabel 11 menunjukkan pemahaman mahasiswa pada Materi konjugasi kata sifat, untuk lebih jelasnya dapat dilihat pada tabel 11:

Tabel 11. Pemahaman Mahasiswa mengenai Konjugasi Kata Sifat

\begin{tabular}{ccc} 
Interval Nilai & Frekuensi & Persentase \\
\hline 1 & 0 & 0 \\
\hline 2 & 0 & 0 \\
\hline 3 & 8 & 20 \\
\hline 4 & 22 & 55 \\
\hline 5 & 10 & 25 \\
\hline 6 & 0 & $\mathbf{1 0 0}$
\end{tabular}

Tabek 11 menunjukkan bahwa materi konjugasi kata sifat juga menjadi materi yang membutuhkan alokasi waktu yang lebih serta membutuhkan penekanan dalam proses pembelajaran dibandingkan beberapa materi lainnya. Hal tersebut dapat dilihat dari tabel 11 yang menjelaskan bahwa sebagian besar mahasiswa berada pada interval 4 dengan persentase $55 \%$.

\section{KESIMPULAN}

Berdasarkan hasil analisis dan pembahasan data, maka dapat disimpulkan bahwa materi mengenai penggunaan preposisi yang menguasai akkusativ dan dativ, materi konjugasi kata sifat, serta materi tingkat perbandingan kata sifat menjadi kesulitan bagi mahasiswa dibandingkan dengan materi-materi lainnya. Selain itu terdapat beberapa materi yang mudah dipahami oleh mahasiswa seperti penggunaan possessivpronomen, modal verben, dan penggunaan nebensatz. Hasil penelitian 
inilah yang dijadikan dasar dalam menyusun buku tatabahasa, sehingga buku yang dikembangkan tersebut berbasis analisis kebutuhan pembelajar.

\section{DAFTAR PUSTAKA}

Aronoff, M. (2017). The handbook of linguistics. John Wiley \& Sons.

Aydınlı, J., \& Ortaçtepe, D. (2018). Selected research in applied linguistics and English language teaching in Turkey: 2010-2016. Language Teaching, 51(2), 210245.

Hinkel, E. (2018). Error Analysis. The TESOL Encyclopedia of English Language Teaching, $1-5$.

Litosseliti, L. (2017). Research methods in linguistics. Bloomsbury Publishing.

Llinares, A., \& Morton, T. (Eds.). (2017). Applied linguistics perspectives on CLIL (Vol. 47). John Benjamins Publishing Company.

Mantasiah \& Yusri. (2017). Analisis Kontrastif Pembentukan Komposita Nomina Verba Bahasa Jerman dan Bahasa Indonesia. Prosiding Konferensi Linguistik Tahunan (KOLITA) : Atmajaya Jakarta.

Mantasiah, R. (2018, June). Pay It Forward Model in Foreign Language Learning to Increase Student's Self Efficacy and Academic Motivation. In Journal of Physics: Conference Series (Vol. 1028, No. 1, p. 012178). IOP Publishing.

Mantasiah, Yusri \& Jufri. (2018). The Development of English Grammar Teaching Material Based on Linguistics Approach. Asian EFL Journal, Oktober 2018.

McDonough, S. (2017). Applied linguistics in language education. Routledge.

Pangaribuan, T., Haddina, E., \& Manik, S. (2018). The Students' Error in Using Conjunction (Because, Since, as, in Case) in the Sentences. English Language Teaching, 11(4), 91.

Song, S. (2018). Second language acquisition theories. In Second Language Acquisition as a Mode-Switching Process (pp. 9-36). Palgrave Pivot, London.

Yusri, Y. (2016). Kesalahan Pembentukan Komposita Nomina Dalam Bahasa Jerman Oleh Mahasiswa Program Studi Pendidikan Bahasa Jerman Fakultas Bahasa Dan Sastra Universitas Negeri Makassar. Jurnal Nalar Pendidikan, 4(1). 